MedieKultur | Journal of media and communication research | ISSN 1901-9726

Article - Open section

\title{
DR3 på flow og streaming \\ - en todelt kanalanalyse
}

\section{Mads Møller Tommerup Andersen}

MedieKultur 2018, 65, 138-157

Published by SMID | Society of Media researchers In Denmark | www.smid.dk

The online version of this text can be found open access at https://tidsskrift.dk/mediekultur

\begin{abstract}
This article conducts a two-tiered analysis of DR3's development within the last five years and finds big differences in the DR3 programmes that dominate the respective ratings for flow TV and streaming: Sports, big music events and a spin-off show are among the most watched on the flow channel while fiction (primarily SKAM) dominates the streaming numbers. This underlines the difficulties in having what the article calls the two-tiered distribution strategy and in having to produce for two different platforms and viewer groups who can have very different genre preferences, which is almost like managing two different TV channels at once. The article's qualitative contribution shows two trends in the channel's many factual programmes - respectively the journalistic experiments and the intimate documentary portraits - which support the DR3 brand's core values concerning brutal honesty, experiments on one's own body and absurdities in society. Compared to the channel's recent fiction strategy, the conclusion points to a channel that can have the potential to be a sandbox channel for DR by testing new programming concepts and time formats. The article also contributes to a discussion of the problems in the measurement of Danish TV ratings, which shows two incompatible measurement paradigms and discusses the inconsistency between flow and streaming in both measurement methods and channel branding.
\end{abstract}




\section{Introduktion}

Da DR3 blev lanceret i januar 2013, var kanalens erklærede mål at sende public service-tv til et yngre segment (15-39 år). Kanalen repræsenterer DR's forsøg på at leve op til public service-kontrakten om at producere indhold til alle befolkningsgrupper og dermed også til de unge. I løbet af sin femårige levetid har kanalen dog været genstand for utallige diskussioner mellem DR-medarbejdere, politikere, kommercielle konkurrenter, anmeldere og seere om, hvordan en public service-kanal til et yngre segment skal forvaltes. Siden DR annoncerede, at DR3's flowkanal vil blive lukket i 2020, og at DR3's programmer udelukkende vil blive tilgængelige via en digital platform (Carlsen, 2017), er det også særligt relevant at kigge på kanalens seertal på henholdsvis flow og streaming. Danskere i aldersgruppen 15-29 år sænkede deres forbrug af flow-tv med 25 procent i 2016 (Knudsen \& Birk, 2016, p.8), men spørgsmålet er, i hvor høj grad kanalens målgruppe vil se DR3's programmer via streaming på dr.dk (DRTV) og på DR's app.

DR3 har ofte været i stærk politisk modvind, men ikke desto mindre har man fortsat kanalens strategi og selvopfattelse om at lave "eksperimenter" (Drivsholm, 2017). I den mediepolitiske debat er DR's kanaler, og navnlig DR3, blevet diskuteret hyppigt, hvor politikere fra Dansk Folkeparti eksempelvis har kritiseret DR3 for at være alt for kommerciel og for at sende alt for mange timers udenlandsk fiktion (Skaarup, Ahrendtsen \& Marinus, 2016). Kanalen er ligeledes blevet kritiseret for at have en gammel seerskare i forhold til kanalens målsætning med en for høj gennemsnitsalder på 46 år (Rahbek, 2013), og DR's kanaler er blevet kritiseret for at sende flere genudsendelser end TV 2's hovedkanal (Fejerskov \& Benner, 2018).

Kanalens levedygtighed er endda blevet diskuteret i DR-skrivelsen "Kortlægning og analyse af DR's aktiviteter og økonomi i 2016", der er lavet på anmodning fra Kulturministeriet og offentliggjort den 5. januar 2018. Ud over at bidrage med økonomiske nøgletal for de enkelte DR-kanalers økonomi og budget til programproduktion (kanalramme), som ikke tidligere har været offentliggjort, diskuterer rapporten blandt andet de økonomiske og public service-relaterede konsekvenser af en total eller delvis lukning af DR3. Kort sagt er DR3 som kanal fortsat genstand for stor organisatorisk og mediepolitisk opmærksomhed. Lægges dette sammen med en målgruppe, som fortrinsvis foretrækker YouTube og Netflix (Heiselberg \& Høy Svenningsen, 2016) samt en skærpet konkurrence fra såvel lokale konkurrenter som udenlandske streamingtjenester, tegner det et billede af et DR3 under et markant pres fra flere sider. Derudover kan man argumentere for, at DR3 er en interessant case at nærstudere, netop fordi kanalen fremover skal blive en rendyrket streamingkanal, og forhåbentlig vil DR forsøge at demonstrere, at tv-mediets digitalisering ikke gør public service-tanken overflødig (McElroy \& Noonan, 2018), men giver DR3 en mulighed for at gå forrest og blive et eksempel til efterfølgelse.

Denne artikel ønsker at gøre status over DR3's hidtidige virke og foretage en indholdsmæssig kortlægning og analyse af DR3's programudbud i løbet af kanalens levetid for at undersøge, om kritikken af kanalens strategiske prioriteringer i forhold til flow-tv og 
streaming er velbegrundet. Artiklens formål er dermed at undersøge: Hvordan prioriterer kanalens strategi henholdsvis flow-tv og streaming, og hvilke udfordringer giver denne prioritering for kanalens brand?

For at kunne diskutere kanalens brand er det nødvendigt først at undersøge, hvilke former for indhold kanalen faktisk har sendt. Men indholdet af en public service-kanal som DR3 bør ikke udelukkende blive evalueret på baggrund kvantitative analyser baseret på estimerede seertal, og derfor leverer artiklen også en kvalitativ analyse af to strømninger i kanalens faktaprogrammer. I de følgende afsnit vil Johnsons teorier om tv-branding sætte den teoretiske ramme for analysen, og derefter vil artiklen diskutere de metodiske udfordringer i Seerundersøgelsen.

\section{Kanalbranding i en digital æra?}

I bogen Branding Television (2012) beskriver den britiske medieforsker Catherine Johnson branding som markedsføring af en mærkevares kvaliteter og værdier, og hun deler brandingen af tv op i tre forskellige niveauer: 1) institutioner/netværk, 2) kanaler, 3) programmer (Johnson, 2012, p.4). Det vil sige, at tv-kanaler kan forstås som selvstændige kanalbrands, som kommunikerer særlige kvaliteter og værdier, men at tv-programmer også er brands i sig selv.

Til trods for at tv-kanalen er fanget mellem vigtigheden af at give synlighed til henholdsvis moderinstitutionen (i dette tilfælde DR) og programmerne, har kanalen ifølge Johnson historisk set været "[...] a central site through which public service provision is evaluated by both viewers and regulators" (Johnson, 2012, p.173). Omvendt kunne man dog argumentere for, at kanaler i den digitale æra kan forekomme næsten usynlige, når modtagerne sagtens kan se DR3-programmer på flow-tv eller streaming uden nødvendigvis at bide mærke i, at DR3 er afsenderen. Især når der streames via DR's hjemmeside eller app, er kanalerne mindre synlige, da indholdet på tværs af alle DR's kanaler er samlet på ét sted under ét moderbrand på institutionsniveau: DR. Længere nede på hjemmesiden er det muligt at sortere, så man kun ser indhold fra DR3, men et sådant fokus på et kanalbrand kræver et aktivt valg fra brugeren. Desuden er det på ingen måde sikkert, at det brand, som afsenderen prøver at kommunikere, stemmer overens med modtagerens opfattelse og oplevelse af brandet (Sepstrup \& Fruensgaard, 2010, p.140).

Johnson peger på en tendens til, at programbrands bliver vigtigere, efterhånden som tv-mediet bliver digitaliseret, da dette tilsyneladende skifte fra push (flow-tv) til pull (streaming) giver seere mulighed for at vælge mere direkte ud fra enkelte programtitler i stedet for at se et kontinuerligt flow af programmer. Johnson antyder, at denne udvikling kan være en trussel for public service-tv, hvor særlige genrer som fiktion og reality vil få større tilslutning på bekostning af det brede mix af vidt forskellige former for tv-programmer, som netop kendetegner public service-tv (Johnson, 2012, p.178; Syvertsen et 
al., 2011), hvilket er på linje med Newcomb \& Hirsch's tanker om tv som et kulturelt og mangfoldigt forum (Newcomb \& Hirsch, 1983).

Den tiltagende digitalisering af $\mathrm{t} v$-mediet og stigende vigtighed af programbrands kan også resultere i, at kanalerne i højere grad bliver målt og vejet ud fra de enkelte programmers værdi frem for hele kanalens output. Denne udvikling ses på DR3, hvor enkelte flagskibsprogrammer promoveres med stor intensitet, men samtidigt sætter kanalen fokus på brede temaer samlet i temauger såsom "Uge Sex" hvert år i uge 6. På DR3's flowkanal vises en uendelig strøm af indhold, og DR3 gemmer gerne de nyeste afsnit af sine flagskibsprogrammer til omkring kl. 21.30, når de konkurrerende kanalers primetime er nogenlunde overstået, mens kanalens sendeflade på andre tidspunkter kan være stærkt domineret af genudsendelser og indkøbte fremmedproduktioner. På hjemmesiden og på app'en vil flagskibsprogrammerne være øverst på siden, når de har premiere eller forpremiere, mens de fleste af fremmedproduktionerne vil være gemt væk medmindre brugeren aktivt søger efter dem.

Digitaliseringen af tv har ført tv-mediet ind $\mathrm{i}$ en ny tid, hvor streamingtjenester også er en del af publikums medieforbrug (Lotz, 2017; Strangelove, 2015). Men for mange tv-institutioners vedkommende er den igangværende periode nærmere en overgangs- eller blandingsfase, hvor institutionerne satser på både flow-tv og streaming på samme tid (Bruun, 2016). Dette gælder også DR og i særdeleshed DR3, hvis målgruppe har vist særligt stor interesse for streamingtjenester med store fiktionsporteføljer (Heiselberg \& Høy Svenningsen, 2016, p.24). Uagtet at DR3's flowkanal har en erklæret udløbsdato, vil kanalen lige nu og i flere år fremover skulle have en todelt distributionsstrategi ved at forsøge at vedligeholde begge distributionskanaler samtidigt. Spørgsmålet er derfor, hvordan man administrerer ét kanalbrand på tværs af to distributionskanaler, hvor indholdet er tilrettelagt på to vidt forskellige måder? Og hvordan kommunikerer man ét kanalbrand til to seerskarer, som givetvis også forbruger indholdet forskelligt - nogle muligvis gennem et ugentligt ritual og andre ved at praktisere bingewatching (Strangelove, 2015). Derfor vil artiklens analyse demonstrere, hvordan denne todelte distributionsstrategi udfordres af bestemte forbrugsmønstre (seertal) på begge platforme.

\section{Metodisk forståelsesramme}

Seerundersøgelsen (tidligere kaldet Tv-Meter) foretages løbende af Kantar Gallup og har siden januar 2017 været baseret på fire forskellige kilder: Basispanelet (ca. 2.600 personer med en tv-boks, som registrerer seningen og sender data automatisk til Gallup), Det Digitale Meterpanel (ca. 1.000 personer, hvis mediebrug måles via en app på deres devices), Webprofilpanelet (ca. 25.000 personer, hvis detaljerede onlineadfærd måles via cookies) og Censusmålingen (totaloptælling af den faktiske webtrafik og onlinesening - målt som antal visninger, men uden at vide, hvem brugerne er - som bruges til at kalibrere streamingtallene mere nøjagtigt). 
Disse fire kilder fusioneres dagligt til ét datasæt i Seerundersøgelsen, som er tilgængelig via abonnement til Kantar Gallups tjenester (se tns-gallup.dk). En potentiel problematik i undersøgelsen er dog, at stikprøven i Det Digitale Meterpanel kun er på 1.000 personer og ikke 2.600 personer, som ellers er kvalitetskravet i basispanelet. Beregningen indeholder derudover ikke noget panel, som måles på både deres flow-tv-sening og deres streaming via andre skærme.

Denne kombination af paneler (gennem en virtuel ekspansion, hvor faktiske seere klones/ganges op til en kunstig konstruktion) udgør også en metodisk udfordring i forhold til den statistiske usikkerhed i Seerundersøgelsen. Denne usikkerhed gælder dog kun de målinger i artiklen, som har med rating at gøre og ikke artiklens målinger af sendetimer, som er baseret på indberetninger fra tv-kanalerne.

Seerundersøgelsen tjener som et værktøj for både branchen og for tv-forskerne i Danmark, og den har siden 1. januar 2017 ved hjælp af de førnævnte paneler inkluderet streaming i sin måling. Men i virkeligheden er der nærmere tale om catch-up-tal, da målingen kun medtager seningen inden for syv dage efter udsendelsen og kun af programmer, som også bliver sendt i flow-tv. Dette er særligt problematisk i DR3's tilfælde, da der kan være tale om en målgruppe, som må formodes at være mere tilbøjelige til at streame indhold, og hvor enkelte populære programmer måske kun bliver publiceret digitalt eller bliver set i en længere periode på over syv dage. Det vil sige, at Seerundersøgelsens måling af streaming hverken inkluderer streaming af programmer, som kun publiceres digitalt, streamingtal for online forpremierer (som DR3 ofte benytter sig af) eller streaming af programmer over syv dage efter premieren på flow-tv, fordi målingen først starter, når programmet har premiere på flow-tv. Hvis streamingtallene efter syv dage skulle medtages, ville en uheldig konsekvens formentlig være, at man skulle vente længere på at offentliggøre de officielle seertal. På grund af de ovennævnte forbehold vælger artiklen også at fremlægge DR Medieforsknings egne streamingtal (som gælder for både 2016 og 2017) frem for Seerundersøgelsens eksisterende streamingtal, som i deres nuværende form er særligt uhensigtsmæssige i forhold til at måle DR3's streamingseere.

Artiklens beregninger af antal sendetimer er baseret på data, som er indberettet af tv-kanalerne. Men eftersom disse data allerede er indsamlet på en bestemt måde og ud fra nogle bestemte kriterier, har jeg ingen indflydelse på eksempelvis udvalget af genrekategorier, da de enkelte tv-programmer er blevet kategoriseret af tv-kanalen. Ved nærmere eftersyn kan disse kategorier være diskutable, da en kategori som "journalistiske programmer" kan dække over stort set hvad som helst fra decideret reality-tv til nyhedsudsendelser. Derudover er der brugt disjunkt klassifikation, hvor hvert program kun kan tildeles én kategori, uagtet om et program som P3 Guld både kan klassificeres som "musik" og som "showprogrammer". Disse genremærkater skal dermed tages med betydelige forbehold, hvilket Helles og Hjarvard ligeledes påpeger (2014, p.62). Nogle tv-kanaler har desuden valgt ikke at informere om bestemte programkarakteristika (f.eks. har TV3 ikke oplyst mængden af fremmedproduktioner), og dermed har et på forhånd indsamlet 
datasæt som Seerundersøgelsen nogle iboende mangler, som desværre ikke umiddelbart kan udbedres. Til gengæld påvirker disse genremærkater hverken selve målingen eller seertallenes gyldighed, og de giver os netop mulighed for at nærstudere, hvilke mærkater kanalen selv har valgt til sine programmer og derigennem opfange eventuelle interessante eller problematiske mærkater.

Analysens udvælgelse af visse variabler frem for andre er et af de få områder i Instar Analytics, som benyttes til at foretage kørsler i Seerundersøgelsen, hvor man som bruger har indflydelse på vinklingen af resultaterne. I udvælgelsen af variabler har jeg inkluderet mængden af førstegangsudsendelser vs. genudsendelser, mængden af egen- og coproduktion vs. fremmedproduktion, vægtningen af forskellige genrer såsom fiktion og journalistiske programmer samt seernes gennemsnitsalder på kanalen. I stedet for at optælle antallet af programmer fokuserer analysen på antal sendeminutter, eftersom det giver et mere retvisende billede, da et enkelt programs længde kan være meget kort eller meget langt og dermed gøre analysen mindre retvisende i forhold til f.eks. mængden af egenproduceret indhold.

Beregningerne er foretaget på årsbasis og har medregnet alle egentlige programmer i løbet af et helt år, men ikke reklameblokke og trailers, som i softwaren Instar Analytics er klassificeret som "ikke-egentlige programmer". For DR3's vedkommende er analysen lavet for hele kanalens levetid i perioden 2013-17, mens analysen af konkurrenterne kun er lavet for 2017 af hensyn til artiklens fokus på DR3 og for at lægge vægt på de allernyeste målinger.

Fortolkningen af tallene er den største udfordring i mange kvantitative undersøgelser, og det skal derfor nævnes, at denne form for seertalsværktøjer primært er blevet udviklet til at tjene medieinstitutionernes marketingsafdelinger og deres reklamesalg. Når jeg her anvender Seerundersøgelsen til et videnskabeligt formål, er det med de samme forbehold, som Helles og Hjarvard påpeger, og for at understrege vigtigheden $i$ at forskere anvender de mest aktuelle tilgængelige data om mediebrugere og medieinstitutioner til at afprøve medievidenskabelige påstande (2014, p.10). Helles og Hjarvard viser, at trods Seerundersøgelsens mangler er der stadig tale om en bredt anerkendt måling, som udgør et meget værdifuldt værktøj for både forskere og brancheaktører i Danmark og giver os en privilegeret mulighed for at måle danske seeres nyeste adfærd.

\section{Kvantitativ analyse af DR3}

Den følgende kvantitative analyse af DR3 i perioden 2013-17 vil først fokusere på flowkanalens udvikling isoleret set, og bagefter vil 2017-tallene blive sammenlignet med de mest oplagte konkurrerende kanaler. Dernæst vil streamingtallene blive inddraget og diskuteret i konteksten af de andre målinger. 
Article: DR3 på flow og streaming

\begin{tabular}{l|l|l|l}
\hline DR3 & RATING(000) & RATING\% & SHARE \\
\hline År 2013 & 17,3 & 0,3 & 1,9 \\
\hline År 2014 & 15,1 & 0,3 & 2,1 \\
\hline År 2015 & 15,4 & 0,3 & 2,2 \\
\hline År 2016 & 15,0 & 0,3 & 2,4 \\
\hline Àr 2017 & 14,6 & 0,3 & 2,5
\end{tabular}

Tabel 1. DR3's rating og share, 2013-17.

Tabel 1 viser DR3's første fem år, hvor kanalens rating (seertallet, dvs. gennemsnitligt antal af seere minut for minut i tusinder) sammenlagt er faldet i løbet af perioden, samtidigt med at kanalens share (andelen af alle de aktive seere) sammenlagt er steget. Når det kan lade sig gøre, at antallet af seere er blevet lavere, samtidigt med at andelen af de aktive seere er blevet større, skyldes det givetvis et generelt fald i antallet af flow-tv-seere. I 2017 viser målingen, at DR3 havde en andel på 2,5 pct. af flow-tv-seerne i Danmark. Et farvel til DR3's flowkanal vil i første omgang for DR dermed også betyde et farvel til en støt stigende share på nu 2,5 pct. af de danske flowseere, selvom DR muligvis ville kunne generobre nogle af disse seere på streaming og gennem de andre DR-kanaler.

Tabel 2 viser antallet af sendetimer fordelt på henholdsvis førstegangsudsendelser og genudsendelser.

\begin{tabular}{l|l|l|l|l|l}
\hline DR3, SENDETIMER & ÅR 2013 & ÅR 2014 & ÅR 2015 & ÅR 2016 & ÅR 2017 \\
\hline Førstegangsudsendelser & 1.237 & 1.747 & 1.327 & 1.442 & 1.200 \\
\hline Genudsendelser & 4.293 & 5.855 & 6.134 & 6.273 & 6.974
\end{tabular}

Tabel 2. DR3's førstegangs- og genudsendelser, 2013-17.

Over hele perioden ligger mængden af førstegangsudsendelser nogenlunde stabilt, men ligger højest i 2014 og ligger lavest i 2017. Mængden af genudsendelser stiger støt i løbet af hele perioden og bidrager dermed til, at det samlede antal sendetimer stiger. I 2017 sendte DR3 i alt 8.174 timers indhold, så når den mediepolitiske debat indimellem kun fokuserer på enkelte programserier som f.eks. Gina Jacqueline - En sugardaters fortcellinger (2017), som tæller for i alt cirka to sendetimer over fire afsnit, diskuterer man egentlig kun 0,02 pct. af kanalens årlige sendetimer.

Tabel 3 viser antallet af sendetimer fordelt på egen-, co- og fremmedproduktion i de seneste fem år, og her ses det, hvordan DR3's fordeling af sendetimer har udviklet sig ganske betydeligt i løbet af perioden.

\begin{tabular}{l|l|l|l|l|l}
\hline DR3, SENDETIMER & ÅR 2013 & ÅR 2014 & ÅR 2015 & Å 2016 & Å 2017 \\
\hline Egenproduktion & 1.144 & 1.607 & 2.705 & 2.978 & 2.759 \\
\hline Coproduktion & 340 & 1.556 & 365 & 318 & 560 \\
\hline Fremmedproduktion & 4.045 & 4.439 & 4.366 & 4.419 & 4.855
\end{tabular}

Tabel 3. DR3's egen-, co- og fremmedproduktion, 2013-17. 
Mængden af egenproduktion stiger kraftigt inden for de første tre år, mens coproduktionerne topper i 2014, som ligger markant højere end de andre år. Dette tyder på, at kanalen i startfasen igangsatte en del coproduktioner i samarbejde med eksterne produktionsselskaber, som så blev sendt i 2014, hvor fordelingen mellem egenproduktion og coproduktion er nogenlunde lige. Dog antyder tallene, at denne tilgang sidenhen blev udfaset til fordel for en større mængde af egenproduktion, som i dag ligger langt over coproduktionen. I de seneste tal fra 2017 lå egenproduktionerne på 33,75 pct., coproduktionerne lå på 6,85 pct. og fremmedproduktionerne tegnede sig for 59,40 pct. af det samlede antal sendetimer. Dermed ligger mængden af originalt indhold produceret til DR3 (egen- og coproduktion) på cirka 40 pct. i 2017, hvortil de resterende cirka 60 pct. er fremmedproduktion.

\begin{tabular}{l|l|l|l|l|l|l}
\hline DR3, SENDETIMER & FIKTION & $\begin{array}{l}\text { JOURNALISTISKE } \\
\text { PROGRAMMER }\end{array}$ & MUSIK & $\begin{array}{l}\text { SHOW- } \\
\text { PROGRAMMER }\end{array}$ & $\begin{array}{l}\text { SNAKKE- } \\
\text { PROGRAMMER }\end{array}$ & SPORT \\
\hline År 2013 & 2.435 & 2.407 & 95 & 157 & 2 & 433 \\
\hline År 2014 & 2.470 & 3.391 & 132 & 998 & 54 & 557 \\
\hline År 2015 & 2.510 & 2.862 & 144 & 1.498 & 113 & 334 \\
\hline År 2016 & 2.472 & 3.105 & 88 & 1.365 & 11 & 674 \\
\hline År 2017 & 2.499 & 3.755 & 74 & 1.433 & 7 & 406
\end{tabular}

Tabel 4. DR3's genrefordeling, 2013-17.

I forhold til genrefordelingen på kanalen viser tabel 4, at mængden af fiktion ligger nogenlunde stabilt i perioden som den næststørste genrekategori kun overgået af "journalistiske programmer", mens "showprogrammer" bliver den tredjestørste kategori fra 2014 og frem. Musik og "snakkeprogrammer" er ikke nævneværdigt en del af kanalens genreudbud, mens sport i højere grad figurerer i optællingen. I 2017 ses det, at sendetimerne er nogenlunde ligeligt fordelt mellem journalistiske programmer på den ene side (3.755 timer) versus fiktion og showprogrammer på den anden side (i alt 3.932 timer).

Med 3.755 timers journalistiske programmer overgår DR3 faktisk DR1, som sendte 3.663 timers journalistiske programmer i 2017. Men hvis man til gengæld gennemgår indholdet i kategorien journalistiske programmer, vil man bemærke to tilbagevendende programserier: Nuttet om natten, der i nattetimerne viser en masse nuttede dyr i forskellige scener, og Morgengymnastikken, der i morgentimerne guider seerne gennem en række forskellige træningsøvelser. Bare i 2017 tæller Nuttet om natten for 799 timer i den journalistiske kategori, mens Morgengymnastikken tæller for 878 sendetimer (som mærkeligt nok er fordelt mellem kategorierne journalistiske programmer og showprogrammer). For begge seriers vedkommende er der tale om relativt billigt indhold, der fylder godt i landskabet på de tidspunkter af døgnet, hvor de færreste ser tv, og som dermed pynter på antallet af sendetimer under både egenproduktion og journalistik. Hvis man derimod fjerner disse to programmer fra DR3's egenproduktion i 2017, falder tallet fra 2.759 timer til 1.082 timer - et fald på 60,78 pct! Andelen af dansksproget, egenproduceret og journalistisk indhold kunne dermed sagtens forstørres ved blot at sende endnu flere timer 
af Morgengymnastikken og Nuttet om natten. Den politiske diskussion om kvantitet i mængden af danskproduceret indhold og antallet af sendetimer klinger dermed hult, da dette nemt kan imødekommes ved hjælp af denne type "rugbrødsprogrammer", som primært skal fylde nogle ledige timer i sendeplanen, og diskussionen kunne i stedet for fokusere på, hvordan man kan understøtte kvalitet i programindholdet.

\begin{tabular}{l|l|l|l|l|l}
\hline KANAL 2017 & SENDETIMER & GENUDSENDELSER & $\begin{array}{l}\text { FREMMED- } \\
\text { PRODUKTIONER }\end{array}$ & $\begin{array}{l}\text { KANALRAMME } \\
\text { (PRIS I MIO. KR.) }\end{array}$ & KR. PR. TIME \\
\hline DR1 & 8.502 & $79,35 \%$ & $54,75 \%$ & 813 & $95.624,56$ \\
\hline DR2 & 8.590 & $78,07 \%$ & $42,75 \%$ & 225 & $26.193,25$ \\
\hline DR3 & 8.174 & $85,32 \%$ & $59,40 \%$ & 132 & $16.148,76$ \\
\hline DR Ultra & 5.632 & $93,71 \%$ & $55,17 \%$ & 96 & $17.045,45$ \\
\hline Ramasjang & 5.132 & $94,89 \%$ & $50,35 \%$ & 46 & 8.963 .37 \\
\hline TV2 & 8.725 & $46,59 \%$ & $26,85 \%$ & $?$ & $?$ \\
\hline TV 2 Zulu & 7.038 & $94,43 \%$ & $70,86 \%$ & $?$ & $?$ \\
\hline TV3 & 8.411 & $?$ & $?$ & $?$ & $?$
\end{tabular}

Tabel 5. Sammenligning mellem DR3 og syv andre kanaler.

I tabel 5 ses DR3 i sammenligning med en række andre danske tv-kanaler i 2017. Tabellen viser, at mængden af genudsendelser på de enkelte kanaler varierer ganske meget med TV 2 som kanalen med det mindste niveau af genudsendelser takket været deres mange daglige nyhedsprogrammer, morgen- og aften-talkshows, regionale nyhedsprogrammer m.m. Til gengæld er DR Ultra, Ramasjang og TV 2 ZULU de tre kanaler, der sender den største andel af genudsendelser (93-94 pct.). Særligt sidstnævnte er interessant, da ZULU også har den største andel af fremmedproduktioner (cirka 70 pct.). Dermed sendte ZULU, der må antages at udgøre en direkte konkurrent til DR3 med den samme unge målgruppe, både flere genudsendelser og færre egen-, co- og entrepriseproduktioner i 2017 end DR3. Dog er det uvist, hvor stort et beløb ZULU har til at købe indhold for, da hverken TV 2 eller TV3 har oplyst dette. Kun DR's kanaler har oplyst disse beløb i "Kortlægning og analyse af DR's aktiviteter og økonomi i 2016", og når disse tal (kanalrammerne) divideres med antallet af sendetimer, udregnes timeprisen for kanalen ( $\mathrm{kr}$. pr. time) i den sidste kolonne.

Denne udregning viser, at DR Ramasjang har den laveste timepris efterfulgt af DR3, som koster 16.148 kr. pr. time, mens DR1 er klart dyrest med 95.624 kr. pr. time. Alt i alt er DR3's værdier målt på de ovenstående parametre ikke de laveste, men heller ikke de højeste i sammenligningen med konkurrenterne.

I forhold til genrefordelingen og gennemsnitsalderen blandt disse otte kanaler viser tabel 6, at DR3's genresammensætning kun matcher nogle af de andre kanaler på enkelte punkter. DR3's andel af sportsudsendelser er næsthøjest kun overgået af TV 2, og DR3's andel af showprogrammer er også næsthøjest kun overgået af TV 2 ZULU. DR2 sender den 
Article: DR3 på flow og streaming

\begin{tabular}{l|l|l|l|l|l|l|l}
\hline KANAL 2017 & FIKTION & $\begin{array}{l}\text { JOURNALISTISKE } \\
\text { PROGRAMMER }\end{array}$ & MUSIK & $\begin{array}{l}\text { SHOW- } \\
\text { PROGRAMMER }\end{array}$ & $\begin{array}{l}\text { SNAKKE- } \\
\text { PROPRAMMER }\end{array}$ & SPORT & $\begin{array}{l}\text { SEERGENNEMSNITS- } \\
\text { ALDER }\end{array}$ \\
\hline DR1 & $45,93 \%$ & $43,08 \%$ & $0,51 \%$ & $3,06 \%$ & $4,63 \%$ & $2,78 \%$ & 57 \\
\hline DR2 & $12,19 \%$ & $82,50 \%$ & $0,03 \%$ & $1,26 \%$ & $3,85 \%$ & $0,16 \%$ & 57 \\
\hline DR3 & $30,57 \%$ & $45,94 \%$ & $0,91 \%$ & $17,53 \%$ & $0,09 \%$ & $4,97 \%$ & 50 \\
\hline DR Ultra & $69,21 \%$ & $20,99 \%$ & $1,23 \%$ & $7,49 \%$ & $0 \%$ & $1,08 \%$ & 25 \\
\hline Ramasjang & $64,82 \%$ & $26,31 \%$ & $0,66 \%$ & $8,21 \%$ & $0 \%$ & $0 \%$ & 23 \\
\hline TV2 & $16,29 \%$ & $70,08 \%$ & $0,17 \%$ & $6,58 \%$ & $0,95 \%$ & $5,93 \%$ & 56 \\
\hline TV 2 Zulu & $64,84 \%$ & $8,38 \%$ & $0,02 \%$ & $24,07 \%$ & $2,64 \%$ & $0,04 \%$ & 43 \\
\hline TV3 & $46,77 \%$ & $44,57 \%$ & $0,02 \%$ & $8,60 \%$ & $0 \%$ & $0,04 \%$ & 48
\end{tabular}

Tabel 6. Sammenligning mellem DR3 og syv andre kanaler ift. genre og seergennemsnitsalder.

største andel af journalistiske programmer, mens DR Ultra, Ramasjang og ZULU hyppigst sender fiktion. I henhold til vægtningen af fiktion og journalistik har nogle af kanalerne en klar overvægt til den ene eller den anden side, mens DR1 og TV3 har et nogenlunde balanceret forhold mellem de to genrer. DR3's blandingsforhold skiller sig ud ved at bestå af cirka 45 pct. journalistiske programmer, 30 pct. fiktion, 18 pct. showprogrammer og 5 pct. sport. Til gengæld har DR3's seere, som påpeget i flere mediepolitiske diskussioner, igen i 2017 en højere gennemsnitsalder (50 år) end seerne på både TV 2 ZULU (43 år) og TV3 (48 år), men en lavere gennemsnitsalder end generalistkanalerne DR1 (57 år) og TV 2 (56 år). Kendetegnende for alle kanaler, undtagen børnekanalerne Ramasjang og Ultra, er, at gennemsnitsalderen blandt flow-tv-seerne er over de 40 år. Så dermed ligger DR3 igen hverken i den høje eller lave ende i forhold til de ovenstående parametre.

I det følgende vil jeg gennemgå de 20 mest sete DR3-programmer (Rating000) i flowtv i perioden 2013-17, da sådan en liste kan fortælle os noget om, hvilke programmer der har været de mest populære og potentielt set har været med til at forme seernes opfattelse af kanalens brand.

Her er det bemærkelsesværdigt, at en af U21-fodboldlandsholdets kampe er det mest sete DR3-program i flow-tv, samt at flere andre sportsudsendelser (blå farve) er blandt de mest populære til trods for, at DR3 ikke rigtigt promoveres som en sportskanal. Næstefter er det programserien Xtra Factor (gul farve), der blev sendt på kanalen i begyndelsen af 2013 som et spinoff af det populære underholdningsprogram X Factor på DR1. Tilstrømningen af seere, der så denne serie, mens der blev sendt Tv-Avisen på DR1, var stor nok til at placere hele fem afsnit af Xtra Factor blandt de mest populære programmer. Derudover står de to store livemusikevents P3 Guld og Eurovision Song Contest (grøn farve) også på listen, hvilket understøtter den almindelige opfattelse af, at liveudsendelser med musik eller sport stadig kan spille en ganske vigtig rolle på flow-tv og samle mange seere. Endeligt er to af DR3's coproducerede faktaprogrammer (rød farve) også med på listen, nemlig Kladt af og Alene i vildmarken. Netop disse to seriers popularitet har formentlig også været medvirkende til, at DR3 kun nåede at lave en enkelt sæson af hver serie, før 


\begin{tabular}{|c|c|c|c|c|c|c|c|}
\hline TITEL & DATO & EPISODE & GENRE & FREKVENS & OPRINDELSE & $\begin{array}{l}\text { SEERGENNEMSNITS- } \\
\text { ALDER }\end{array}$ & RATING (000) \\
\hline $\begin{array}{l}\text { U21 EM fodbold: Tjekki- } \\
\text { et-Danmark, direkte }\end{array}$ & $17-06-2015$ & & Sport & Serie & Egenprod. & 49 & 362,1 \\
\hline U21 EM fodbold: Studiet & 17-06-2015 & & Sport & Serie & Egenprod. & 48 & 354,3 \\
\hline Xtra Factor & 04-01-2013 & & $\begin{array}{l}\text { Show- } \\
\text { programmer. }\end{array}$ & Serie & Egenprod. & 35 & 340,1 \\
\hline $\begin{array}{l}\text { VM håndbold: } \\
\text { Frankrig-Norge, direkte }\end{array}$ & 15-01-2017 & & Sport & Serie & Egenprod. & 53 & 267,9 \\
\hline Klædt af & 14-01-2015 & 1 & \begin{tabular}{|l|} 
Journalistiske \\
programmer
\end{tabular} & Serie & Coprod. & 47 & 265,3 \\
\hline Xtra Factor & $11-01-2013$ & & \begin{tabular}{|l} 
Show- \\
programmer
\end{tabular} & Serie & Egenprod. & 34 & 265,1 \\
\hline Xtra Factor & 15-02-2013 & & $\begin{array}{l}\text { Show- } \\
\text { programmer }\end{array}$ & Serie & Egenprod. & 31 & 259,6 \\
\hline P3 Guld 2013 & 27-03-2013 & & Musik & \begin{tabular}{|l|} 
Enkelt \\
udsendelse
\end{tabular} & Egenprod. & 38 & 258,7 \\
\hline Klædt af & 21-01-2015 & 2 & \begin{tabular}{|l|} 
Journalistiske \\
programmer
\end{tabular} & Serie & Coprod. & 39 & 256,2 \\
\hline VM håndbold & 15-01-2017 & & Sport & Serie & Egenprod. & 54 & 249,8 \\
\hline Alene i vildmarken & 04-01-2017 & 2 & $\begin{array}{l}\text { Journalistiske } \\
\text { programmer }\end{array}$ & Serie & Coprod. & 50 & 236,0 \\
\hline Sherlock & $10-01-2016$ & & Fiktion & \begin{tabular}{|l|} 
Enkelt \\
udsendelse
\end{tabular} & Fremmedprod. & 47 & 234,7 \\
\hline P3 Guld 2014 & 04-04-2014 & & Musik & \begin{tabular}{|l} 
Enkelt \\
udsendelse
\end{tabular} & Egenprod. & 39 & 234,4 \\
\hline $\begin{array}{l}\text { VM håndbold: } \\
\text { Frankrig-Sverige, direkte }\end{array}$ & 24-01-2017 & & Sport & Serie & Egenprod. & 57 & 229,2 \\
\hline $\begin{array}{l}\text { Efterfesten: } \\
\text { Mer' Grand Prix! }\end{array}$ & $10-05-2014$ & & $\begin{array}{l}\text { Show- } \\
\text { programmer }\end{array}$ & Serie & Egenprod. & 44 & 222,7 \\
\hline $\begin{array}{l}\text { VM håndbold: } \\
\text { Frankrig-Norge, direkte }\end{array}$ & 15-01-2017 & & Sport & Serie & Egenprod. & 55 & 215,0 \\
\hline Xtra Factor & $22-02-2013$ & & \begin{tabular}{|l|}
$\begin{array}{l}\text { Show- } \\
\text { programmer }\end{array}$ \\
\end{tabular} & Serie & Egenprod. & 37 & 213,6 \\
\hline Xtra Factor & 22-03-2013 & & \begin{tabular}{|l} 
Show- \\
programmer
\end{tabular} & Serie & Egenprod. & 31 & 213,2 \\
\hline $\begin{array}{l}\text { Eurovision Song Contest } \\
2014 \text { med Monte Carlo }\end{array}$ & $10-05-2014$ & & $\begin{array}{l}\text { Show- } \\
\text { programmer }\end{array}$ & Serie & Egenprod. & 38 & 212,6 \\
\hline Alene i vildmarken & 01-01-2017 & 1 & $\begin{array}{l}\text { Journalistiske } \\
\text { programmer }\end{array}$ & Serie & Coprod. & 49 & 211,3 \\
\hline
\end{tabular}

Tabel 7. De 20 mest sete programmer på DR3 i flow-tv, 2013-17.

Farverne signalerer genrer i denne sammenhæeng, ncermere bestemt sportudsendelser (blå), Xtra Factor (gul), livemusikevents (grøn), faktaprogrammer (rød) og fiktion (pink).

hovedkanalen DR1 overtog dem, og de kan dermed ikke længere regnes blandt DR3brandets flagskibsprogrammer. Samlet set viser denne liste et ganske interessant billede af et DR3, hvor faktaprogrammer og fiktion bliver overgået af sport, musikevents og en spinoffserie. Det er dog vigtigt at præcisere, at en top 20 med ratingtal som denne ikke rummer alle facetter af seeradfærden, men fokuserer på de mest populære programmer i perioden. Hvis man gik længere ned på listen, ville man bemærke episoder af Gift ved første blik (2013), Min krop til skrcek og advarsel (2014) og Fuckr med dn hjrne (2013) med en rating på 150.000-200.000. 
For at kunne vurdere DR3's popularitet på henholdsvis flow-tv og streaming er det nødvendigt at kigge nærmere på streamingtallene fra DR Medieforskning.

I tabel 8 ses det gennemsnitlige antal af seere per minut (dvs. rating) for de 20 mest sete DR3-programmer på streaming i 2016 og 2017. Disse streamingtal (Netrating Gemius) fra DR Medieforskning er estimater baseret på tal fra Gemius og Adobe Analytics, som dækker sening on demand via DR's hjemmeside og app. Tendensen her er tydelig: Den norske serie SKAM (NRK P3, 2015-17) har uden sidestykke været den mest sete DR3programserie på streaming. Kun et enkelt egenproduceret afsnit af Prinsesser fra Blokken (2016) er med i top 20. Længere nede på listen under alle SKAM-episoderne ville man kunne se, at flere af DR3's egen- og coproducerede programmer har episoder med en netrating på over 200.000 i perioden såsom Gina Jacqueline - en sugardaters bekendelser

\begin{tabular}{l|l|l|l} 
TITEL & $\begin{array}{l}\text { FVRSTE STREAMING } \\
\text { DATO }\end{array}$ & $\begin{array}{l}\text { FORSTE } \\
\text { UDSENDELSESDATO }\end{array}$ & $\begin{array}{l}\text { NETRATING } \\
\text { GEMIUS }\end{array}$ \\
\hline Skam (1:11) & $01-12-2016$ & $01-12-2016$ & 835.600 \\
\hline Skam II (1:12) & $12-12-2016$ & $12-12-2016$ & 633.600 \\
\hline Prinsesser fra Blokken (1:4) & $10-11-2016$ & $14-11-2016$ & 591.200 \\
\hline Skam II (6:12) & $12-12-2016$ & $17-12-2016$ & 500.300 \\
\hline Skam II (7:12) & $12-12-2016$ & $18-12-2016$ & 487.700 \\
\hline Skam II (3:12) & $12-12-2016$ & $14-12-2016$ & 487.100 \\
\hline Skam (2:11) & $01-12-2016$ & $02-12-2016$ & 485.300 \\
\hline Skam IV (1:10) & $15-04-2017$ & $16-04-2017$ & 480.100 \\
\hline Skam (4:11) & $01-12-2016$ & $04-12-2016$ & 476.300 \\
\hline Skam (7:11) & $01-12-2016$ & $07-12-2016$ & 471.400 \\
\hline Skam (3:11) & $01-12-2016$ & $03-12-2016$ & 470.500 \\
\hline Skam II (5:12) & $12-12-2016$ & $16-12-2016$ & 463.800 \\
\hline Skam (5:11) & $01-12-2016$ & $05-12-2016$ & 454.600 \\
\hline Skam II (9:12) & $12-12-2016$ & $20-12-2016$ & 448.400 \\
\hline Skam II (2:12) & $12-12-2016$ & $13-12-2016$ & 440.200 \\
\hline Skam IV (2:10) & $22-04-2017$ & $23-04-2017$ & 437.200 \\
\hline Skam II (11:12) & $12-12-2016$ & $22-12-2016$ & 431.600 \\
\hline Skam (6:11) & $01-12-2016$ & $06-12-2016$ & 430.200 \\
\hline Skam II (12:12) & $12-12-2016$ & $23-12-2016$ & 430.100 \\
\hline Skam IV (5:10) & $13-05-2017$ & $14-05-2017$ & 426.200
\end{tabular}

Tabel 8. De 20 mest sete DR3-programmer på streaming, 2016-17. 
(2017), Prinsesser fra Blokken, Samtaler fra Swingerklubben (2017), Gulddreng vs. Malthe (2017), Hård udenpå (2017) og Alene i vildmarken (2017). Datoerne i tabel 7 viser desuden, at programindholdet som regel havde forpremiere på streaming nogle få dage, inden det var tilgængeligt via flow-tv, og denne tendens afspejles også hos de fleste andre DR3-programmer i resten af den streamingmåling, som jeg modtog fra DR.

Herudfra kan det konkluderes, at selvom SKAM ikke var blandt de mest sete programmer i flow-tv, overgik den alle andre DR3-programmer på streaming. Dog skal det noteres, at programmerne på streaming kan være tilgængelige i en ganske lang periode, og at vi her ikke umiddelbart har mulighed for at se, hvor længe programmet var tilgængeligt, eller hvor mange streamingseere det havde om dagen eller om ugen. Det vil sige, at en netrating på 300.000 godt kan dække over et program, som kun havde 10.000 streamingseere om dagen i 30 dage, hvilket kan beskrives som forholdsvis lavt set i forhold til flow-tv-seningen.

Problemet med de to ovenstående målinger på hhv. flow-tv og streaming er, at de to sæt tal er grundlæggende uforenelige. I flow-tv laves der et estimat, som kun gælder for seningen inden for syv dage, mens der på streaming kan måles over en meget længere periode. Streamingmålingen giver DR3 mulighed for at gå ud at sige, at der nu er 591.000, som har set Prinsesser fra Blokken. Det lyder umiddelbart som et højt og flot tal for en dansk nichekanal med en share på 2,5 pct., fordi vi af erfaring forstår seertal ud fra flowtv-konteksten. Men hvis det eksempelvis har taget en måned at få programmet til at nå ud til 591.000 seere, kan antallet af seere per dag stadig være relativt lavt, og dette viser blot, at streamingtal kalder på en ganske anderledes forståelse af programmers holdbarhed og seeradfærd. Her kan vi blot håbe på fremover, at mere nuancerede målinger fordelt på uger, dage og timer forhåbentligt bliver tilgængelige og kan give os et bedre indblik i disse aspekter af seeradfærden.

\section{DR3's egen- og coproducerede fiktionsserier}

En analytisk gennemgang af DR3's programudbud bør rettelig også nævne kanalens egenog coproducerede fiktionsserier. Denne kategori af programmer udgør ikke en specielt stor del af kanalens sendeflade, men eftersom målgruppen ifølge DR Medieforskning nævner fiktion som sit yndlingsindhold (Heiselberg \& Høy Svenningsen, 2016, p.24), er det relevant at kortlægge dette område mere grundigt.

Jeg har valgt ikke at inkludere beregningen af seertallene for disse fiktionsserier, da der er tale om små tal. Disse serier, der er nævnt i tabellen ovenfor, er formentlig ukendte for mange danskere, da de fleste af DR3's egen- og coproducerede fiktionsserier i perioden hverken har haft høje seertal (hverken i flow-tv eller på streaming) eller mange omtaler i pressen. Enkelte serier har fået positive anmeldelser i pressen, heriblandt de tre eksternt producerede serier, Anton 90, Yes No Maybe og Joe Tech (eksempelvis i Soundvenue 


\begin{tabular}{l|l|l|l|l}
\hline FIKTIONSSERIER & ÅR & PRODUCERET AF & EPISODER & MIN. PR. EPISODE \\
\hline Kolonien & $2012-13$ & DR Ung & 16 & $8-10$ \\
\hline Kødkataloget & $2013-14$ & DR Ung & 14 & 18 \\
\hline Anton 90 & 2015 & New Creations & 10 & $8-9$ \\
\hline Julie og Jesper & 2016 & DR Ung & 5 & $7-8$ \\
\hline Generation SoMe & 2017 & DR Ung & 6 & 9 \\
\hline Yes No Maybe & 2017 & Good Company Films & 8 & $11-13$ \\
\hline Joe Tech & 2017 & Nordisk Film Spring & 8 & 18 \\
\hline Jaloux & 2017 & DR Ung & 5 & 3 \\
\hline Krisministeren & 2017 & DR Ung & 10 & 11 \\
\hline Monrad - I seernes tjeneste & 2017 & DR Ung & 6 & 27 \\
\hline Magic Mrtin & 2017 & DR Ung & 5 & 5 \\
\hline Hvad er det værste der kan ske? & 2017 & DR Ung & 5 & 3 \\
\hline 2013-16: Fire produktioner på fire år/ca. 581,5 minutter = 129,625 minutter pr. år & \\
\hline
\end{tabular}

2017: Syv produktioner på ét år/54+96+144+15+110+162+25+15 = 621 minutter pr. år

Tabel 9. DR3's egen- og coproducerede fiktionsserier, 2013-17.

og Politiken). Tabellen viser dog også et klart skifte i DR3's sparsomme fiktionsstrategi (Andersen, 2017) fra 2016 til 2017, hvor mængden af egen- og coproduceret fiktion per år mere end firedobles. Kanalen producerede pludseligt flere fiktionsserier end tidligere, samtidigt med at de enkelte serier generelt havde færre episoder, hvilket peger på en slags sandkassestrategi med mange små/korte forsøg i mange forskellige formater i stedet for at brænde alle midlerne af på én dyr produktion. DR3 manglende popularitet på fiktionsfronten er desuden også blevet anerkendt af kanalchef Irene Strøyer tilbage i november: "Vi er lykkedes mindre godt med vores satirestrategi, hvor vi ikke helt har fundet fodfæste. Det ærgrer mig lidt. Programmet Monrad, eksempelvis, fungerede ikke optimalt" (Drivsholm, 2017). Fiktionsserien SKAM havde, som nævnt ovenfor, den største gennemslagskraft online, hvilket kan tænkes at være en del af forklaringen på, hvorfor DR3 i 2016-17 pludseligt satser på at producere markant mere fiktion i forhold til tidligere. At konkurrenten TV 2 ZULU allerede har profileret sig på at lave fiktion (særligt comedy) til den samme målgruppe (Hansen, 2018), gør således DR3's øgede satsning inden for dette område endnu mere bemærkelsesværdig. De kommende år vil vise, om DR3's stigende produktion af fiktionsserier fortsætter til trods for de udeblivende seerhits på denne front.

\section{Kvalitativ analyse af DR3's faktaprogrammer}

Mens fiktionssatsningerne ikke har tiltrukket sig specielt stor opmærksomhed, ser billedet anderledes ud for kanalens faktaprogrammer. Artiklens kvalitative påstand er, at der 
iblandt DR3's egen- og coproducerede faktaprogrammer i kanalens femårige levetid kan findes mindst to tydelige strømninger, der repræsenterer de fleste af de flagskibsprogrammer, som er blevet benyttet hyppigt $i$ kanalens branding og egenreklame.

Den ene strømning udgøres af en række "journalistiske eksperimenter", hvor en gruppe almindelige danskere skal gennemgå en proces med en række opstillede benspænd (f.eks. en datingproces) designet på baggrund af nogle "videnskabelige" input (f.eks. psykologi). Prototypen på denne journalistisk-eksperimenterende strømning er Gift ved første blik (2013-17), som fik premiere i 2013, og som DR3 lykkedes at sælge som format til udenlandske tv-kanaler, mens de efterfølgende sæsoner er blevet overtaget og sendt af hovedkanalen DR1. Andre eksempler på programmer, der kan inkluderes i denne strømning, er Menneskeforsøg (2014-17), Fuckr med dn hjrne (2013-17), Ond, Ondere, Ondest (2014), Smerteeksperimentet - LIVE fødslen (2014), Fuckr med døden (2014), Kløedt af (2015), Sandhedseksperimentet - en cerlig halv time (2016), Menneskejagt (2016), Billet til kerlighed (2016-17), Alene i vildmarken (2017-18), Koden til kerlighed (2018), m.fl. I disse programmer udsættes en gruppe almindelige unge danskere for et ekstraordinært "eksperiment" med det formål at gøre seerne klogere på et tema såsom kroppen, ondskab, manipulation, dating, overvågning, materialisme, seksualitet etc.

Den anden strømning udgøres af en række intime dokumentariske portrætter, som går tæt på en eller flere unge med en særlig udfordring eller et unikt talent, og kameraet er oftest som fluen på væggen, der forholdsvis passivt dokumenterer begivenhederne og lader det være op til seeren selv at forholde sig til indholdet. Prototypen på denne strømning af dokumentariske portrætter kunne være Prinsesser fra Blokken (2016), som følger en gruppe unge kvinder fra Vestegnen, der lever i en kultur præget af technofester, skoletræthed og en tung social arv. Andre eksempler på programmer, der kan inkluderes i denne strømning, er De Uperfekte (2013), Selvoptaget (2014), Syg i hovedet (2014), Min krop til skrcek og advarsel (2014), P.O.V. (2015-16), De Smukke Drenge (2016), Drengene på kanten (2016), Samtaler fra swingerklubben (2017), De Smukke Piger (2017), Sex på recept (2017-18), I Forreste Rekke (2017), Tykke Ida (2017), Siri - en prinsesse gi'r aldrig op (2017), Gina Jacqueline - en sugardaters fortelling (2017), Hård udenpå (2017), Simona overlever (2018), Fuckbois (2018), m.fl. I modsætningen til den første strømning viser disse programmer oftest en gruppe ekstraordinære unge danskere, hvis hverdag er præget af en række helt særlige omstændigheder, og som titlerne viser, fokuseres der i højere grad på de enkelte personers særpræg. Programmerne går gerne tæt på samfundets kropsidealer, forestillingerne omkring det perfekte og det uperfekte, samt unge i problemer eller unge i marginaliserede grupper.

Begge strømninger bærer i nogen grad præg af reality-tv, hvis genredefinition kan være vanskelig at fastholde, men Anne Jerslev nævner i sit forsøg på en definition, at reality-tv's udgangspunkt oprindeligt var almindelige mennesker i ikke-scriptede situationer filmet fra en observerende, dokumentarisk eller overvågende kameraposition. Jerslev tilføjer dog hertil, at reality-tv-programmer ofte iscenesætter intimitet og følelser, er tværme- 
diale, indeholder et interaktivt element og er serialiserede (Jerslev, 2014, p.23). Flere af programmerne i begge strømninger passer på denne definition og fremstår til tider som inspirerede af realitydokumentaren og af, hvad Caroline Dover og Annette Hill kalder det formatterede sociale eksperiment (Dover \& Hill, 2007, p.23). Realitygameshowet/ konkurrencen synes også at have inspireret DR3's journalistiske eksperimenter dog med det forbehold, at DR3's programmer sjældent er konkurrencer, hvor deltagerne stemmer hinanden ud, men nærmere narrative processer, hvor deltagerne skal klare det næste trin i deres personlige udfordring. Hermed skiller DR3's programmer sig ofte markant ud fra flere andre realityprogrammer, da det i eksempelvis i Alene i vildmarken er op til deltagerne selv, om de ønsker at forlade programmet. Således fokuserer programmernes narrativ næsten aldrig på det sociale rænkespil mellem deltagerne, men på den enkeltes udfordringer og gevinster ved f.eks. at turde satse på kærligheden eller ved henholdsvis at fortsætte eksperimentet eller stoppe med at deltage.

Det kan derudover diskuteres, om der kan siges at have været en tredje strømning med en række værtsdominerede programmer omkring tilbagevendende værtsprofiler som Petra Nagel, Thomas Skov, Jan Hellesøe, Peter Falktoft og Esben Bjerre, m.fl. De to sidstnævnte værtsprofiler stoppede med at lave tv til DR3 i slutningen af 2015, og den værtsdominerede strømning knytter sig for øjeblikket primært til kanalens tre andre værtsprofiler.

Denne kvalitative analyse kan sammenholdes med kanalchef Irene Strøyers udtalelser i Information, hvor hun beskriver kanalbrandet ud fra, hvad hun kalder "det grønne DR3filter":

\footnotetext{
Vi arbejder ikke med klassiske genre- eller målgruppedefinitioner. I stedet har vi udviklet 'Det grønne DR3-filter', som er de tre tilgange, alt vores indhold filtreres gennem. For det første er DR3's indhold hudløst ærligt, ægte og råt. For det andet skal vi være seernes wingman og lave eksperimenter på egen krop, så de ikke behøver at opleve alt selv. Og for det tredje skal vi sætte fokus på absurditeterne i vores liv og samfund (Drivsholm, 2017).
}

Strøyers beskriver i sin kernesætning om det grønne DR3-brand (farven skyldes kanalens grønne logo) et fokus på hudløs ærlighed, eksperimenter på egen krop og absurditeter i samfundet, hvilket passer ganske godt på de to nævnte strømninger i kanalens faktaprogrammer. Men programmerne i disse to strømninger er til gengæld ikke blandt de meste sete programmer i flow-tv og på streaming. Spørgsmålet er således, om hvor populært eller tydeligt kanalens brand er, når det er kvalitativt synligt i to strømninger i programudbuddet, men kvantitativt mere usynligt i seertallene. Denne problematik for DR3's brand er desuden forstærket af det faktum, at tre af de mere populære programserier blev overtaget af DR1 (Gift ved første blik, Klcedt af og Alene i vildmarken). 


\section{Konklusion}

På baggrund af en omfattende kortlægning af et stort empirisk datamateriale kan artiklens analyse sammenfattende præsenteres i tre pointer, der beskriver, hvordan DR3 som kanal fremstår vidt forskellig alt efter, om man ser på kanalens flowtal eller streamingtal:

1) Hvis man ser på de DR3-programmer, som har haft størst popularitet på flow-tv i kanalens levetid, ser man et genrebillede af et DR3, hvor sport, live-musikevents og en spinoffserie overgår genrer som fiktion og dokumentarserier, som DR3 ellers gerne vil fokusere på i brandingen af kanalen. Feltet med de mest sete DR3-programmer på flow-tv er således sammensat af vidt forskellige genrer, som kun i mindre grad har været en del af kanalens ansigt udadtil, og som passer dårligt til kanalbrandets kerneværdier om hudløs ærlighed, eksperimenter på egen krop og absurditeter i samfundet.

2) Hvis man ser på de mest populære DR3-programmer på streaming i 2016-17, viser tallene, at fiktionsserien SKAM var det klart mest populære DR3-indhold på streaming. SKAM overgik dermed DR3's egne fiktions- og satireserier, hvoraf flere dog stadig opnåede en netrating på over 200.000. Denne tendens bør ses i lyset af, at kanalens egne fiktionsog satiresatsninger haft svært ved at slå igennem, men SKAM's popularitet samt undersøgelser af målgruppens præferencer for fiktion har formentlig ført til, at DR3 i 2017 mere end firedoblede sin egen- og coproduktion af fiktion. Kanalen producerede pludseligt flere fiktionsserier end tidligere, samtidigt med at de enkelte serier blev kortere, hvilket peger på en slags sandkassestrategi med mange små forsøg. Når dette sammenholdes med DR1's overtagelse af en række DR3-programmer, kan DR3 beskrives som en potentiel sandkassekanal for DR, hvor en række forskellige koncepter og tidsformater afprøves i DR3's programmer, som sidenhen kan overføres til DR1, hvis de vurderes at have en bredere seerappel. Dette er dog kun sket i begrænset udstrækning indtil videre.

3) Hvis man ser på DR3's egen- og coproducerede flagskibsprogrammer, som kanalen selv fremhæver og benytter til kanalbranding, viser der sig et ganske andet billede, som afspejler kanalbrandets kerneværdier mere klart. Her har den kvalitative analyse fremhævet to tydelige strømninger blandt kanalens faktaprogrammer: de journalistiske eksperimenter og de intime dokumentariske portrætter. Ud af disse strømninger kan man se DR3's publikumsforestillinger, og hvordan kanalen ved hjælp af en række samfundsrelevante temaer og casting af usædvanlige unge forsøger at appellere til målgruppen.

Det grønne DR3-filter og de to strømninger i faktaprogrammerne viser, at man forsøger at gøre DR3 til et genkendeligt brand. Spørgsmålet er dog, i hvor høj grad den mission er lykkedes, da tallene fra især flow-tv viser et andet billede. Sammenfattende viser dette, at DR3's kanalbrand netop er selektivt og gerne vil være kendt for nogle bestemte genrer, og at de har lagt et stort stykke arbejde i at lave en tematiseret programproduktion og i at udvikle to særlige typer faktaprogrammer. Her har artiklens analyse påvist det paradoksale i kanalens todelte distributionsstrategi og i, at kanalen må tage hensyn til to forskellige platforme, to forskellige måleparadigmer og potentielt set to vidt 
forskellige seerskarer. Det er næsten, som om DR3 skal administrere to forskellige tvkanaler på én gang. På den ene side giver de to platforme også DR3 to muligheder for at opnå stor seertilslutning, hver gang kanalen lancerer et nyt flagskibsprogram. Men på den anden side peger kanalbrandingens fokus på disse flagskibsprogrammer med forpremierer på streaming efterhånden mere i retningen af en kanal, hvis brand først og fremmest henvender sig til streamingseerne. Med forpremierer på streaming og en høj vægtning af streaming frem for flow synes det er være DR3's intention, at målgruppen på 15-39 år netop ikke skal se flow-kanalen, men skal finde DR3's indhold online. Her prioriteres hovedkanalen DR1's behov på flow over nichekanalen DR3's behov, og DR forsøger måske i nogen grad at samle sine flow-tv-seere på DR1.

På et dansk flow-tv-marked, hvor en stor mængde genudsendelser og fremmedproduktioner samt en høj gennemsnitsalder er ganske almindeligt, skiller DR3 sig ikke markant ud men følger en middelvej, hvor kanalen hverken ligger i toppen eller bunden med sit programudbud, men alligevel har færre genudsendelser og færre fremmedproduktioner end den direkte konkurrent TV 2 ZULU. Den mediepolitiske debat har ofte handlet om disse aspekter af kanalens udbud, men denne analyse har demonstreret, at DR3 forsøger sig med mange egenproduktioner (til en lav timepris). Den politiske diskussion omkring antal sendeminutter er ligeledes misforstået, da disse tal let kan pumpes op ved at sende store mængder af egenproducerede "journalistiske programmer" på skæve tidspunkter af døgnet som f.eks. Nuttet om natten. Spørgsmålet er dog, om disse rugbrødsprogrammer bør fjernes, når man skal opgøre, hvad DR3's egenproduktion reelt set består af, og selve antallet af sendeminutter bør derfor ikke være det eneste parameter. Derimod kunne diskussionen med fordel fokusere på kvaliteten i programmerne velvidende, at det ikke er et kvantificerbart fokus. Men seertal bør heller ikke være det eneste parameter, som man vurderer en public service tv-kanal ud fra.

Ligeledes kan man spørge: Hvorfor insisterer DR3 på at sende over 8.000 timers flowtv hvert år, hvoraf 60 pct er fremmedproduktioner, når nu kanalen efter sigende ønsker at fokusere mere på egen- og coproduktion samt på streamingindhold? Hvorfor nøjes DR3 ikke med at sende f.eks. 4.000 timer og fokuserer midlerne, så de muligvis kan sikre en højere kvalitet $i$ indholdet? Et eventuelt svar kunne være, at hvis først man decimerer antallet af sendetimer, kunne det tolkes som et signal til politikerne om, at kanalen kan undværes og ikke magter at producere indhold til hele sendefladen, hvilket DR naturligvis ikke ønsker. Derudover kan DR3's flowindhold tælles med i DR's samlede opgørelser og sørge for, at DR lever op til sine public service-forpligtelser.

\section{DR3 i fremtiden}

At en todelt distributionsstrategi kan give problemer med at tydeliggøre kanalbrandet, er en relevant problematik for de fleste danske tv-kanaler, som benytter samme strategi. Men idet DR3 er rettet mod de 15-39-årige, har DR givetvis valgt, at DR3 fremadrettet skal 
prioritere streaming frem for flow-tv, og set i lyst af DR3-brandets manglende evne til at rumme de store seerhits på flow-tv og kanalens øgede prioritering af streaming har denne beslutning muligvis været nem at træffe. Men i stedet for at decimere finansieringen af indhold til unge og overlade opgaven til kommercielle kanaler, som det bliver diskuteret $\mathrm{i}$ øjeblikket, kunne man vælge at prioritere de unge for at sikre, at public service-institutionerne også i fremtiden når ud til alle aldersgrupper (en lignende problematik ses hos BBC Three, beskrevet i Woods, 2017; Ramsey, 2016). Forhåbentlig kan denne analyses resultater bruge til at diskutere, hvordan tv-kanalernes todelte distributionsstrategi stiller dem i en udfordrende situation og kan resultere i et lettere skizofrent kanalbrand, men at en sådan udfordring kalder på fortsat udvikling af distributionsplatforme samt på politisk og finansiel opbakning hertil. Selvom DR3's flow-kanal skal lukke i 2020, har DR3 dog stadig en række udfordringer foran sig, og de kommende års overgangsperiode vil vise, om DR3 kan finde frem til den rette kanalstrategi, som kan tilfredsstille både seerne, politikerne og DR som institution.

\section{Referencer}

Andersen M.M. (2017). Negotiating Creativity on a Small Budget: Creative Assumptions in DR3's TV Commissioning, Nordicom Review 39 (2018), vol. 39, nr. 1, s. 19-32. DOI: 10.1515/nor-2017-0418. Bruun, H. (2016). The Prism of Change: 'Continuity' in Public Service Television in the Digital Era, NORDICOM Review: Nordic Research on Media and Communication, vol. 37, nr. 2, s.1-17. DOI: 10.1515/nor-2016-0016.

Dover, C. \& Hill, A. (2007). Mapping Genres: Broadcaster and Audience Perceptions of Makeover Television. I D. Heller (red.), Makeover Television. Realities Remodelled, (s. 23-38). London: I.B. Tauris. Hansen K.T. (2018). SJIT Happens og ungdoms-tv. I G. Agger, J.R. Christensen \& L.B. Jacobsen (red.), (s. 217-233). Tvanalyse. Aarhus: Systime.

Heiselberg, L. \& Høy Svenningsen, U. (2016). Streamingtjenester vinder fortsat terræn. I DR Medieforskning (red.) Medieudviklingen, (s. 22-29). København: DR Medieforskning. https://www.dr.dk/NR/rdonlyres/ EDBEE3F4-5C3E-439E-A08E-870734C3CD72/6150035/medieudviklingen_2016.pdf.

Helles, R. \& Hjarvard, S. (2014). Seertal og webtrafik. Frederiksberg: Samfundslitteratur. Jerslev, A. (2014). Reality-tv. Frederiksberg: Samfundslitteratur. Johnson, C. (2012). Branding television, Abingdon. Oxon: Routledge.

Knudsen, H.G. \& Birk, M. (2016). Flow er stærkest, men streaming mærkes. I DR Medieforskning (red.) Medieudviklingen, (s. 6-11). København: DR Medieforskning. https://www.dr.dk/NR/rdonlyres/ EDBEE3F4-5C3E-439E-A08E-870734C3CD72/6150035/medieudviklingen_2016.pdf.

Lotz, A. D. (2017). Portals: A Treatise on Internet-Distributed Television. Michigan: Michigan Publishing. McElroy, R. \& Noonan, C. (2018) Public Service Media and Digital Innovation. Th e Small Nation Experience. I G.F. Lowe, H. Van den Bulck \& K. Donders (red.) Public Service Media in the Networked Society, (s. 159-174). Gothenburg: Nordicom.

Newcomb, H.M. and Hirsch, P.M. (1983). Television as a cultural forum: implications for research, Quarterly Review of Film Studies, vol. 8(3), s. 45-55. DOI: 10.1080/10509208309361170. 
Article: DR3 på flow og streaming

Ramsey, P. (2016). 'It could redefine public service broadcasting in the digital age': Assessing the rationale for moving BBC Three online, Convergence: The International Journal of Research into New Media Technologies, vol. 4(2), s. 152-167. DOI: 10.1177/1354856516659001.

Sepstrup, P. \& Fruensgaard, P. (2010). Tilrettelaggelse af information: kommunikations- og kampagneplanleegning. Århus: Academica.

Strangelove, M. (2015). Post-TV: Piracy, Cord-Cutting, and the Future of Television. University of Toronto Press.

Syvertsen, T., Ihlebæk, K.A. \& Ytreberg, E. (2011). Farvel til mangfoldet? - Endringer i norske tv-kanalers programlegging og sendeskjemaer etter digitaliseringen. Norsk medietidsskrift, vol. 18, s. 217-238.

Woods, F. (2017). Streaming British Youth Television: Online BBC Three as a Transitional Moment, Cinema Journal, vol. 57, s. 140-146.

Tak til Hans-Peter Degn og Rasmus Rørdam Lund for metodisk assistance.

Mads Møller T. Andersen

Ph.d.-studerende

Aarhus Universitet

Afdeling for Medievidenskab og Journalistik

mandersen@cc.au.dk 